\title{
The Debt of Developing Countries: Another Look
}

THE purpose of this report is to reexamine the debt of developing countries in the light of the second "oil shock." In 1977, when the dollar price of OPEC oil was less than $\$ 13$ a barrel, I undertook such an exercise and, on the basis of data through 1975 or 1976, came to optimistic conclusions about the capacity of nonoil developing countries to continue to incur debt. ${ }^{1}$ As it turned out, the supply of funds available to those developing countries that are major borrowers from banks remained ample at low real interest rates through 1978, when the OPEC surplus disappeared. In fact, the contraction of the OPEC surplus in the years immediately following the first OPEC price shock had its counterpart not in a reduction of the aggregate current account deficit of nonoil developing countries, as I expected in 1977, but in a shift to surplus by the industrial countries as a group.

Today, when the average price of OPEC oil is near $\$ 35$ a barrel, the deficits of nonoil developing countries look much larger in nominal terms. New debt has grown in relation to the assets and capital of banks. A larger proportion of new borrowing is from banks rather than from official sources. Furthermore, interest rates on new bank loans have risen sharply. It is reasonable to ask, therefore, whether the heavy borrowers among nonoil developing countries still appear creditworthy.

To provide a basis for comparison, I first review the financing of deficits of developing countries in 1974-78. Then the "debt burden" and the economic performance of the eight largest borrowers are examined.

1. Robert Solomon, "A Perspective on the Debt of Developing Countries," BPEA, 2:1977, pp. 479-501. 
This is followed by a brief discussion of the relations among inflation, interest rates, and debt. Finally I ask, as in 1977, what could go wrong?

\section{Recycling in 1974-78}

By 1978, just before the second large rise in oil prices, the OPEC surplus on the current account (goods, services, and private transfers) was close to zero. Even Saudi Arabia, which had a current surplus of \$24 billion in 1974-almost two-fifths of the aggregate OPEC surplus-was near balance in 1978; in fact, when official transfers are included, Saudi Arabia had a deficit in 1978.

The pattern of current account positions had by 1978 returned to the pre-1974 norm: a $\$ 30$ billion surplus for the industrial countries, matched more or less by a $\$ 38$ billion deficit for the nonoil developing nations. ${ }^{2}$ Although the current deficit of the latter group was about the same nominal magnitude as in 1974, it was smaller in real terms and as a proportion of their GNP, which had grown in real terms about 5 percent a year.

In the five years from 1974 to 1978 the cumulative current account deficit of nonoil developing countries came to just over $\$ 180$ billion. $^{3}$ It turned out to have been financed remarkably smoothly. In fact, these countries as a group managed to add $\$ 39$ billion to their reserves. Thus their net capital inflow, including official grants, was about $\$ 220$ billion.

A part of the $\$ 220$ billion supplied to developing countries in 1974-78 - $\$ 65$ billion, or 30 percent-did not add to their debt because it came in the form of direct investment or official grants. Another $\$ 37$ billion was in official concessionary loans, which went to the poorer countries, while almost $\$ 20$ billion was borrowed from official sources on nonconcessionary terms. ${ }^{4}$

2. A number of so-called nonoil developing countries are now net exporters of oil-for example, Egypt, Malaysia, Mexico, Peru. In the remainder of this paper I use the terms non-OPEC and nonoil interchangeably. The aggregate data in this and the next section include South Africa and several countries in Europe, which I exclude from non-OPEC less-developed countries (LDCs) in the tables below.

3. Unless otherwise indicated, all data on balance of payments and its financing are from International Monetary Fund, Annual Report, 1981 (hereafter IMF).

4. IMF, Annual Report, 1980, p. 32. 
The other major source of financing was bank lending, which was concentrated in a relatively small number of advanced developing countries. Net bank lending to all nonoil developing countries amounted to $\$ 90$ billion in 1974-78, comprising 41 percent of the current account deficit and reserve increase of these countries. ${ }^{5}$ When questions are raised about the future recycling process, it is the durability of this source of finance that is in doubt, either because the major borrowers may lose creditworthiness from the standpoint of banks or because the banks or their regulators fear overexposure-that is, too high a proportion of their assets tied up in this form.

\section{Impact of the Second Increase in Oil Prices}

The weighted average price of OPEC crude oil increased about 170 percent from the end of 1978 to early 1981 . The OPEC surplus on the current account reemerged, reaching $\$ 112$ billion in 1980 . The deficit of all nonoil developing countries jumped from less than $\$ 38$ billion in 1978 to $\$ 82$ billion in 1980 . Of the increase of $\$ 45$ billion, some $\$ 24$ billion was attributable to the trade balance in oil. Although some elements in the current account moved toward surplus, the increase in payments of interest that came from both the rise in interest rates and the growth of debt led to a $\$ 22$ billion shift to larger deficit in "gross investment income" of nonoil developing countries. ${ }^{6}$ As Jeffrey Sachs and others have pointed out, when the rate of inflation increases, current account deficits tend to overstate the true debtor position since higher nominal interest payments, included in the current account, are matched by a real reduction in debt, which is not reflected in the current account. ${ }^{7}$

One-third of the increase in the current account deficit was financed by a near cessation in the accumulation of reserves, from almost $\$ 16$ billion in 1978 to just over $\$ 1$ billion in 1980 . Another $\$ 7$ billion came from an increase in long-term borrowing from official sources. Although pub-

5. IMF, "International Capital Markets: Recent Developments and Short-Term Prospects, 1981," Occasional Paper 7 (IMF, August 1980), p. 74.

6. IMF, World Economic Outlook (IMF, June 1981), pp. 122, 129.

7. Jeffrey D. Sachs, "The Current Account and Macroeconomic Adjustment in the 1970s," BPEA, 1:1981, pp. 201-68; and IMF, "External Indebtedness of Developing Countries," Occasional Paper 3 (IMF, May 1981), pp. 12-16 and appendix 2. 
licly announced Eurocurrency bank credits decreased slightly, total international bank lending to nonoil developing countries rose sharply, from $\$ 22$ billion in 1978 to $\$ 38$ billion in $1980 .^{8}$

\section{Questions for the Future}

Once again, uncertainty exists about the size and duration of the OPEC surplus in the years ahead. Many observers believed, at least until recently, that the real price of oil was more likely to be maintained this time, in contrast to its decline in 1974-78. Doubts have been expressed again about the capacity of the OPEC countries to increase imports rapidly. On the other hand, the so-called oil glut and Saudi Arabia's success in forcing down the prices being charged by other oil exporters cast doubt on the contention that the real price will be prevented from falling. Furthermore, if Iran and Iraq, whose output and exports of oil are depressed as the result of their war, should restore normal output and Saudi Arabia should reduce its output correspondingly, a larger proportion of OPEC revenues would be spent and the OPEC surplus could contract substantially.

A major change from the time my earlier article was written is the sharp increase that occurred in real interest rates on bank loans to developing countries. In 1977 the interest rate on three-month deposits in the Eurodollar market averaged 6 percent. In mid-1981 it was 17-3/4 percent. The rate of inflation in the industrial countries, as measured by the advance of consumer prices, has risen much less-from 8.4 percent in 1977 and just under 10 percent in mid-1981. The rate of interest on all outstanding debt was below the current rate but was probably rising fast given that a large proportion of bank loans carry floating interest rates and that the major borrowers receive only a small part of their capital inflow in the form of loans from official sources carrying relatively low, fixed interest rates.

In the growth-cum-debt model set forth in my 1977 article, the debtincome ratio converges to a limit if the real (or nominal) rate of growth exceeds the real (or nominal) rate of interest. That condition is not met

8. Morgan Guaranty Trust Company of New York, "World Financial Markets," (September 1981), p. 16; and Bank for International Settlements, "International Banking Developments: First Quarter 1981" (July 1981), table 6, and preceding issues. 
Table 1. External Bank Debt, Selected Years, 1975-80

Billions of dollars, end of period

\begin{tabular}{lrrrr}
\hline & \multicolumn{4}{c}{ Bank debt } \\
\cline { 2 - 5 } \multicolumn{1}{c}{ Country } & 1975 & 1978 & 1979 & 1980 \\
\hline Argentina & 3.2 & 6.7 & 13.1 & 18.9 \\
Brazil & 14.8 & 31.7 & 36.9 & 43.3 \\
Chile & 0.8 & 2.7 & 4.5 & 6.7 \\
Mexico & 13.5 & 23.2 & 30.7 & 41.0 \\
Peru & 2.3 & 3.4 & 3.6 & 3.9 \\
Philippines & 2.0 & 4.0 & 5.4 & 7.0 \\
South Korea & 3.3 & 6.9 & 10.3 & 14.0 \\
Thailand & 1.2 & 2.7 & 3.0 & 3.2 \\
$\quad$ Total & 41.1 & 81.3 & 107.5 & 138.0 \\
$\quad \begin{array}{l}\text { Addenda } \\
\text { All non-OPEC LDCs }\end{array}$ & & & & \\
Eight countries as a proportion & 63.0 & 120.8 & 155.9 & 193.5 \\
$\quad$ of all non-OPEC LDCs & 0.65 & 0.67 & 0.69 & 0.71 \\
Brazil as a proportion & & & & \\
$\quad$ of all non-OPEC LDCs & 0.23 & 0.26 & 0.24 & 0.22 \\
\hline
\end{tabular}

Source: Bank for International Settlements, "International Banking Development: Second Quarter 1981" (November 1981), tables 6 and 7, and preceding issues.

a. Nonoil developing countries excluding South Africa and countries in Europe.

at the interest rates prevailing in 1981, and debt accumulation could be characterized as an explosive process rather than a self-limiting one.

On the assumption that interest rates will come down, I turn to an assessment of the creditworthiness of the major borrowers among developing countries.

\section{The Debt Position of Major Borrowers}

As noted above, a significant proportion of the aggregate current account deficit of nonoil developing countries is financed by bank loans. Yet only a small number of developing countries are major borrowers from banks. As table 1 shows, eight countries account for more than 70 percent of the bank debt of all nonoil developing countries. These eight countries, often referred to as newly industrialized, account for half of the GNP and nearly half of the combined current account deficit of all nonoil developing countries. The eight countries are responsible for a 
substantial proportion of the net oil imports of developing countries. In 1978, for example, Argentina, Brazil, Chile, the Philippines, South Korea, and Thailand had combined net oil imports of $\$ 9.4$ billion, which was just about half of the net oil bill of all nonoil-exporting developing countries. (The latter group excludes not only members of OPEC but also countries such as Egypt, Mexico, and Peru, which are net exporters of oil.)

Brazil and Mexico continue to be major debtors of banks. Because Brazil is singled out for more detailed analysis below, it is worth observing that it accounts for more than one-fifth of the bank debt of all nonOPEC developing countries.

Although bank debt for the eight countries tends to be a higher proportion of total debt than for developing countries in general, these eight also had a large amount of other forms of debt, much of it at fixed interest rates, in contrast to the variable rate paid on most bank debt.

While these eight countries held a smaller fraction of total than of bank debt, as would be expected, they still account for more than half of the total debt (over one year) of all non-OPEC developing countries. Once again Brazil stands out with $\$ 55$ billion, or 18 percent of total debt in 1980. But it should be stressed that Brazil also accounts for nearly one-fifth of the GNP of all non-OPEC developing countries.

\section{The Burden of Debt}

As indicated in my 1977 article, the traditional debt-service ratio (interest plus amortization as a proportion of exports of goods and services) is a defective measure of debt burden. Table 2 shows the ratio of annual interest payments to export of goods and services, although this ratio is defective also because it is biased upward by inflation. Even if the percentage point increase in nominal interest rates were no greater than the acceleration of export prices, the proportionate rise in interest rates would be a multiple of the proportionate rise in prices. For example, assume both the inflation rate and interest rate rose from 5 to 10 percent. The price level would be 5 percent higher after a year, but interest rates would have doubled. Thus the measure used here exaggerates the increase in debt burden in periods when inflation accelerates and interest rates rise correspondingly. 
Table 2. Interest Payments as a Percent of Export Proceeds, 1973-80

\begin{tabular}{lrrrrrrrr}
\hline \multicolumn{1}{c}{ Country } & 1973 & 1974 & 1975 & 1976 & 1977 & 1978 & 1979 & $1980^{\mathrm{a}}$ \\
\hline Argentina & 5.3 & 7.8 & 11.0 & 8.3 & 7.1 & 9.6 & 10.1 & 13.5 \\
Brazil & 5.5 & 15.7 & 20.4 & 15.0 & 14.8 & 21.3 & 26.1 & 28.2 \\
Chile & 2.6 & 4.9 & 11.7 & 11.0 & 10.1 & 12.1 & 12.1 & 15.1 \\
Mexico & 7.1 & 12.8 & 17.4 & 18.9 & 19.4 & 18.3 & 20.5 & 18.3 \\
Peru & 7.1 & 10.3 & 16.0 & 17.6 & 16.4 & 17.9 & 13.3 & $12.7^{\mathrm{b}}$ \\
Philippines & 1.3 & 3.0 & 3.8 & 4.8 & 5.3 & 6.3 & 7.6 & 6.9 \\
South Korea & 5.5 & 4.1 & 5.3 & 4.5 & 3.8 & 4.0 & 4.8 & 6.0 \\
Thailand & 1.2 & 2.5 & 3.4 & 3.1 & 3.0 & 3.9 & 4.7 & 5.4 \\
All non-OPEC & & & & & & & & \\
$\quad$ LDCs & 4.4 & 3.8 & 4.8 & 4.5 & 4.6 & 5.5 & 6.5 & 7.4 \\
\hline
\end{tabular}

Sources: World Bank; last row, IMF, World Economic Outlook (IMF, June 1981), p. 135.

a. Calculated by the author based on World Bank data on interest payments and IMF balance-of-payments data from International Financial Statistics, vol. 34 (October 1981), pages on individual countries.

b. Based on exports of goods and services in first half of 1980.

Since 1973 all but one of the eight countries experienced significant increases in the ratio of annual interest payments to exports of goods and services. South Korea's ratio was held down by the phenomenal growth of its exports. Peru's position has changed since its debt rescheduling of 1978 as the result of its oil exports and the improvement in its current account. The countries for which the ratio is both high and rising are Brazil and, less clearly, Mexico. For the other countries, the share of export proceeds that are preempted by interest payments on external debt is relatively small. It appears that only two of the eight countries have a potential debt burden problem.

Before looking at Mexico and Brazil in greater detail, I examine the economic performance of the eight countries.

\section{Economic Performance of Major Borrowers}

As a basis for judging creditworthiness, my 1977 article examined not only measures of debt burden but also indicators of economic performance. These indicators are reviewed in this section.

The rates of growth of real GDP in the eight countries are shown in table 3. Brazil, the Philippines, South Korea (except for 1980), and Thailand have maintained persistently strong rates of growth since 1970 . Mexico's growth accelerated in $1978-80$ to quite a high rate. Chile's 
Table 3. Rates of Growth of Real Output, 1970-80

Percent per year

\begin{tabular}{lrrrrrrr}
\hline \multicolumn{1}{c}{ Country } & $\begin{array}{c}1970-74, \\
\text { average }\end{array}$ & 1975 & 1976 & 1977 & 1978 & 1979 & 1980 \\
\hline Argentina & 5.2 & -0.9 & -1.7 & 4.9 & -3.4 & 8.5 & 1.1 \\
Brazil & 11.5 & 5.7 & 9.0 & 4.7 & 6.0 & 6.4 & 8.0 \\
Chile & 2.6 & -11.3 & 4.1 & 8.6 & 7.8 & 8.5 & 6.5 \\
Mexico & 6.2 & 4.1 & 2.1 & 3.3 & 7.3 & 8.0 & 7.4 \\
Peru & 6.3 & 3.3 & 3.0 & -1.2 & -1.8 & 3.8 & 3.1 \\
Philippines & 6.7 & 5.9 & 6.1 & 7.0 & 7.6 & 6.0 & 5.4 \\
South Korea & 9.9 & 8.1 & 13.9 & 10.1 & 11.3 & 7.1 & -3.4 \\
Thailand & 7.0 & 7.1 & 8.7 & 7.2 & 10.1 & 6.1 & 6.3 \\
All non-OPEC & & & & & & & \\
$\quad$ LDCs & $6.0^{\mathrm{a}}$ & 4.0 & 5.4 & 4.8 & 5.5 & 4.9 & 4.4 \\
\hline
\end{tabular}

Sources: For the Latin American countries until 1979-United Nations Commission for Latin America, as reported in Financial Times, June 29, 1981, p. I; for 1980 data-Inter-American Development Bank, Economic and Social Progress in Latin America: 1980-81 Report, p. 400; other countries, IMF, International Financial Statistics, vol. 34 (October 1981), pages on individual countries; for all non-OPEC LDCs, IMF, Annual Report, 1981, p. 12.

a. For the $1973-74$ period.

economic performance improved markedly after 1976. Peru and Argentina have grown erratically and, on average, much more slowly than the other six countries; both, as noted, have relatively low debt burdens.

Except for Peru, all eight countries increased exports in 1970-79 much faster than the average for all middle-income developing countries, as displayed in table 4. Furthermore, export expansion accelerated in the 1970s for most of the eight countries, in contrast to the record of all middle-income developing countries. As noted above, Korea's exports increased at an almost unbelievable rate.

Considering the sluggish import expansion of the industrial countries since 1973 -averaging only 3.3 percent annually-the export performance of most of the eight countries is striking. It should be noted that Peru's exports began to increase again after 1976. Moreover, as an oil exporter, it is making up in higher prices the shortfall in its export volume.

It should also be pointed out that the figure for export growth of Brazil in table 4 is contradicted by data from another source. According to statistics of the International Monetary Fund derived from the Getulio Vargas Foundation, the volume of Brazil's exports, including coffee, increased at a compound annual rate of 9.1 percent in 1970-79 (and 10.1 percent in 1970-80). Excluding coffee, which comprised 12 percent of 
Table 4. Rate of Increase of Volume of Exports, 1960-79

Percent per year

\begin{tabular}{lcc}
\hline \multicolumn{1}{c}{ Country } & $1960-70$ & $1970-79$ \\
\hline Argentina & 3.4 & 10.7 \\
Brazil & 5.1 & $7.0^{\mathrm{a}}$ \\
Chile & 0.6 & 10.7 \\
Mexico & 2.8 & 10.9 \\
Peru & 2.0 & 1.7 \\
Philippines & 2.2 & 6.2 \\
South Korea & 34.1 & 25.7 \\
Thailand & 5.2 & 12.0 \\
Low-income nonoil LDCs & 5.0 & -1.0 \\
Middle-income oil-importing LDCs & 6.3 & 4.4 \\
\hline
\end{tabular}

Source: World Bank, World Development Report, 1981, pp. 148-49.

a. See text for a different estimate.

the value of exports in 1980, the volume of exports rose 13.4 percent annually in 1970-80. ${ }^{9}$ On this basis, Brazil's export performance seems considerably more impressive.

As another measure of performance, table 5 presents the available data on the ratio of gross fixed capital formation to gross domestic absorption. ${ }^{10}$ Although the information is spotty, it can be seen that since 1973 Chile, Mexico, Peru, the Philippines, South Korea, and Thailand have increased the share of available resources used for fixed investment. These countries are not borrowing merely to maintain consumption in the face of higher oil prices. Brazil shows a small decrease after 1976 in the share of absorption devoted to capital formation. This was accompanied by a reduction in the current account deficit as a proportion of GDP.

\section{A Closer Look at Mexico and Brazil}

Even though Mexico's petroleum exports amounted to about $\$ 10$ billion in 1980, nearly two-thirds of total merchandise exports, market

9. IMF, International Financial Statistics, Yearbook 1981 (IMF, 1981), p. 125.

10. The rationale for this formulation of the measure of resources devoted to capital formation is given in Solomon, "A Perspective on the Debt," p. 498. Another reason is to eliminate the inflation bias in GNP, which is reduced by interest payments abroad, though a part of these payments represents amortization of debt under conditions of inflation. 
Table 5. Gross Fixed Capital Formation as a Percentage of Total Absorption, Selected Years, 1973-80

\begin{tabular}{lrrrrr}
\hline \multicolumn{1}{c}{ Country } & 1973 & 1976 & 1978 & 1979 & 1980 \\
\hline Argentina & 20.1 & 22.6 & 21.6 & n.a. & n.a. \\
Brazil & 22.7 & 23.1 & 21.7 & 21.1 & 21.4 \\
Chile & 12.9 & 9.1 & 14.3 & 14.8 & 16.7 \\
Mexico & 20.2 & 21.4 & 22.2 & 24.8 & n.a. \\
Peru & 12.6 & 15.7 & 14.5 & 15.9 & 17.2 \\
Philippines & 16.0 & 23.0 & 22.6 & 23.4 & 24.0 \\
South Korea & 23.1 & 23.2 & 29.7 & 30.2 & 28.8 \\
Thailand & 20.1 & 21.2 & 23.9 & 24.5 & 25.0 \\
\hline
\end{tabular}

Source: IMF, International Financial Statistics, various issues, pages on individual countries. n.a. Not available.

a. Total absorption is GDP minus exports plus imports of goods and services.

participants have been disturbed by the scale at which Mexico has found it necessary to borrow abroad. ${ }^{11}$ Furthermore, capital flight and downward pressure on the exchange rate have been reported. In fact, the dollar value of the peso fell about 8 percent in the first ten months of 1981 . While this would not be noteworthy in most other Latin American countries, Mexico's economic links to the United States make the maintenance of a stable exchange rate desirable, even though Mexico's rate of inflation exceeds 25 percent a year.

Mexico's current account deficit increased from $\$ 3.3$ billion in 1978 to $\$ 7.5$ billion in 1980 despite the fact that the country had become a net exporter of oil. As Sachs has argued, a major reason for the enlarged current account deficit was the substantial increase in capital formation as a fraction of available resources, as shown in table $5 .^{12}$ The Mexican peso may also have been overvalued in this period. Given the high rate of investment, the strong rate of growth, and the availability of oil, it is hard to believe that Mexico will not continue to look like a good credit risk.

As is well known, Brazil's rate of inflation is extremely high. Whatever the political and social effects, no one seems to be attributing much, if any, of Brazil's balance of payments and debt problems to inflation. Monetary correction and the crawling-peg exchange rate are an old story in Brazil.

Several aspects of the external position of the economy deserve atten-

11. See, for example, The Journal of Commerce, July 2, 1981, p. 23B.

12. Sachs, "The Current Account and Macroeconomic Adjustment," p. 232. 
tion if one is trying to assess Brazil's capacity to carry additional debt. The current account deficit increased from $\$ 7$ billion to $\$ 12.9$ billion between 1978 and 1980. The trade deficit, with imports measured c.i.f., increased by $\$ 2.5$ billion. This increase in the trade deficit was considerably less than the $\$ 5.7$ billion increment in the landed cost of petroleum imports during this period. What is remarkable is that from 1979 to 1980 , despite a near doubling of the price of oil and an increase in the dollar value of oil imports by $\$ 3.5$ billion, Brazil's trade deficit was unchanged. Real GNP grew at a rate of about 8 percent but the volume of imports declined 6.5 percent. Export volume, including coffee, increased about 23 percent.

Over a longer period it is even more remarkable that the volume of Brazil's imports in 1980 was below the level of 1975, while real GDP was up nearly 40 percent. Import substitution appears to be at work, but not at the expense of export expansion. Export volume increased about 63 percent from 1975 to $1980 .{ }^{13}$ By now more than half of Brazil's exports consist of industrial products, including airplanes sold to commuter airlines in the United States. Thus the Brazilian economy is demonstrating resilience and the ability to supply attractive products in its export markets.

The only fly in the ointment is the interest on external debt. From 1978 to 1980 , when external debt (with maturity over one year) increased by $\$ 8.5$ billion, annual gross interest payments rose $\$ 3.5$ billion (from $\$ 3.1$ billion to $\$ 6.6$ billion). This rise in interest was equal to three-fifths of the increase in the current account deficit. Gross interest payments as a proportion of average debt outstanding during the year (estimated by averaging year-end data) advanced from about 7.7 percent in 1978 to 12.3 percent in 1980, somewhat less than the increase in average Eurodollar yields. ${ }^{14}$ If interest rates had remained at the 1978 level, gross interest payments would have been $\$ 2.5$ billion lower in 1980 . About two-thirds of the increment in interest payments from 1978 to 1980 was accounted for by the advance in interest rates and one-third by the increase in debt. Since 1980, market interest rates have risen considerably further.

In these circumstances, Brazil has imposed restrictive policies on do-

13. All data are from IMF, International Financial Statistics, vol. 34 (December 1981), pp. 90-93.

14. Data on interest payments and debt outstanding are from the World Bank. 
mestic activity and on imports. Imports have fallen and Brazil registered a trade surplus in the first ten months of 1981 , but at the cost of a recession. Industrial production fell in 1981. Even if the external accounts, excluding interest, are brought into balance, interest on the debt already outstanding at the end of 1980 at interest rates prevailing in late October would require gross interest payments by Brazil of roughly $\$ 7-1 / 2$ billion a year, larger than the current account deficit in 1978.

At current levels of interest rates, the burden of servicing debt is heavy. I now turn to this problem and its relation to inflation.

\section{Inflation, Interest Rates, and Debt}

During much of the 1970 s real interest rates in the industrial countries were negative or, if positive, very low. ${ }^{15}$ This favorable condition, from the viewpoint of borrowing countries, changed beginning in 1979 .

Part of the advance in interest rates matched the acceleration of inflation. Such an increase in nominal interest rates speeds up debt amortization, compensating for the reduction in the real value of debt. As Sachs puts it: "A rise in inflation that is exactly matched by a rise in interest rates causes a rise in interest income for a creditor country that is exactly offset by greater capital losses." 16

By the same token, the short-term burden of higher interest payments on the debtor countries is offset by the reduction in the real value of debt. In effect, accelerated amortization occurs.

When nominal interest rates rise by more than the acceleration of inflation, as has happened, an uncompensated burden is imposed on borrowers. The magnitude of the burden is a function of the size and duration of the increase in real interest rates. The burden shows up in enlarged current account deficits, which in turn require heavy borrowing and engender doubts about creditworthiness. As Brazil has demonstrated this year, debtor countries respond with actions that cut back on their imports and their rates of growth. This in turn affects the exports of industrial

15. Sachs, "The Current Account and Macroeconomic Adjustment," p. 225.

16. Ibid., p. 206. I am grateful to Ralph C. Bryant, William Cline, and Jeffrey D. Sachs for helping to straighten me out on the relation between inflation and the interest burden on developing countries. 
countries. Thus if real interest rates do not come down soon, the outlook for debt-financed economic development is bleak. But a drop in real interest rates brought on by recession in industrial countries would not be helpful because the benefit from lower interest payments would be offset by reduced exports by developing countries.

\section{What Could Go Wrong}

The major borrowers among developing countries weathered the first oil shock rather well, justifying the optimism expressed in my 1977 article. One reason for this outcome was that the industrial countries, in the aggregate, restored a reasonably satisfactory rate of expansion in real GNP after the recession of 1975. Although expansion in Europe and Canada was rather sluggish, Japan and the United States pulled up the average. If the industrial countries do not emerge from the stagnation evident in 1980-81, the developing countries will have problems in exporting and in servicing debt. It is difficult to say anything fresh about this or about the dangers of protectionism in the industrial countries.

Whether the banks will be deterred from continuing to lend because they will reach exposure limits is beyond the scope of this paper. ${ }^{17}$ There is little evidence that this will be a serious problem in the medium-term future. It is true that U.S. bank claims on developing countries have increased much faster than bank capital since the second oil shock was felt in $1979 .{ }^{18}$ Just as the current account deficits of the major borrowers declined in real terms after the first oil shock, they are likely to decline again this time, assuming that the industrial countries restore reasonable rates of expansion that permit continued growth of LDC exports. In this case, the rate of increase of bank loans is likely to fall.

Finally, it is possible to envision a much larger role for the International Monetary Fund and a smaller role for the banks, should that become necessary, to keep the recycling process going.

17. For a survey of bankers' views, see Group of Thirty, "The Outlook for International Bank Lending," 1981.

18. Henry C. Wallich, "LDC Debt-To Worry or Not To Worry," Remarks at the 59th Annual Meeting of the Bankers' Association for Foreign Trade, Boca Raton, Florida, June 2, 1981, p. 7. 


\section{Conclusions}

The record of the major bank borrowers among developing countries is favorable. Even when debt burden is measured by interest on external debt as a proportion of exports of goods and services, which exaggerates the burden when interest rates rise with inflation, only Brazil and Mexico of the eight countries need to be looked at closely from the viewpoint of creditworthiness. Mexico's oil and its prospects for continued rapid growth are strong elements in its creditworthiness. Brazil's export performance and its ability to compress imports provide a good deal of assurance about its capacity to prevent its external debt from becoming unmanageable even in the short run. In the longer run, the Brazilian "miracle" should go on and, with it, a reasonably strong external position should continue. In general, therefore, one can conclude that the eight countries are creditworthy.

It does not follow that lenders, especially bankers, will share this view or that other obstacles such as exposure limits will not interfere with the recycling process. If the economic growth of developing countries is to continue, not only must existing maturities be refinanced but additional financing must be made available to cover the inevitable current account deficits of the next few years. It is commonly accepted that the International Monetary Fund will play a larger role, not by "bailing out" the banks but by supplementing commercial bank lending and providing a "seal of approval."

If a substantial OPEC surplus persists, it may become necessary for the international financial community to consider innovative means of finance -means that will assure the siphoning of funds from OPEC to oilimporting countries in deficit. Without this, the world economy could slip into much worse stagnation than anything witnessed in recent years. For now there is comfort to be taken from the economic and financial positions, past and present, of those non-OPEC developing countries that have been the heaviest borrowers from commercial banks.

All this assumes that the exceedingly high real interest rates of 1981 will come down and stay down. If that assumption does not materialize, not only the advanced developing countries but the world economy will be in serious trouble. 


\section{Discussion}

JEFFREY SACHS noted that the international lending markets seem to regard loans to less-developed countries as low in risk. This could be inferred from the interest rate premiums charged on these loans, which have remained extraordinarily low over recent years. John Shoven suggested several explanations for the low interest rate premiums. Banks might provide economic and military assistance to many of the borrowing countries, and the borrowers might fear the cessation of aid in the event of default. Or the chance of default might genuinely be very low, contrary to naive expectations, because the costs of default to the borrowing country are quite high. By repudiating its debts, a country would be indefinitely prevented from borrowing again. Sachs added that there have in fact been only two debt repudiations by LDCs in the postwar period-by Ghana (which was later converted to a rescheduling) and by North Korea. In both cases, the costs to the defaulting country were substantial, since even normal trade flows could not be financed. In addition, there are no known cases in which commercial banks rescheduled LDC debt at an interest rate below the market rate. Thus to all appearances the loans are reasonably safe. Donald Hester agreed that the margins on international loans have recently been small but pointed out that profit margins in large multinational American banks have sharply declined in recent years, suggesting that necessary rollovers of LDC debt might be unprofitable.

Ralph Bryant observed that Brazil's impressive success in containing its trade balance is partly due to dampening imports through restrictive policies and encouraging exports through subsidy arrangements. $\mathrm{He}$ pointed out that such policies could not be pursued successfully throughout the world as a whole, and not even by all developing countries, without risking slow growth and stagnating trade. Consequently, these policies should not be construed as a model for widespread adoption by developing countries. 